\title{
Synthesis of Some Transition Metal Complexes of a Novel Schiff Base Ligand Derived from 2,2'-bis( $p$-Methoxyphenylamine) and Salicylicaldehyde
}

\author{
Xishi Tai ${ }^{1, *}$, Xianhong Yin ${ }^{1,2}$, Qiang Chen ${ }^{1}$ and Minyu Tan ${ }^{1}$ \\ ${ }^{1}$ College of Chemistry and Chemical Engineering, Lanzhou University, Lanzhou, 730000, P. R.China. \\ ${ }^{2}$ Chemistry Department, Guangxi University for Nationalities, Nanning, 530006, P. R. China. \\ * Author to whom correspondence should be addressed; e-mail: taixishi@1zu.edu.cn
}

Received: 25 February 2003; in revised form: 3 April 2003 / Accepted: 5 April 2003 / Published: 31 May 2003

\begin{abstract}
A novel Schiff base ligand derived from 2,2'-bis( $p$-methoxyphenylamine) and salicylicaldehyde and its transition metal complexes with $\mathrm{Cu}$ ( II), Co ( II ) and Mn ( II) have been synthesized. Their spectral properties and electrochemical behavior were investigated.
\end{abstract}

Keywords: Schiff base; transition metal complexes; synthesis; properties.

\section{Introduction}

During the past two decades, considerable attention has been paid to the chemistry of the metal complexes of Schiff bases containing nitrogen and other donors [1-4]. This may be attributed to their stability, biological activity [5] and potential applications in many fields such as oxidation catalysis [6], electrochemistry [7], etc. Herein we report the synthesis of a novel Schiff base ligand $\left(\mathrm{H}_{2} \mathrm{~L}\right)$ and its $\mathrm{Cu}$ (II), Co (II) and Mn (II) complexes. Their spectral properties and electrochemical behavior were investigated. 


\section{Results and discussion}

\section{Ligand synthesis}

The ligand $\left(\mathrm{H}_{2} \mathrm{~L}\right)$ was prepared as outlined in Figure 1.

Figure 1. Synthesis of the ligand<smiles>COc1ccc(N)c(-c2cc(OC)ccc2N)c1</smiles><smiles>COc1ccc(/N=C/c2ccccc2O)c(-c2cc(OC)ccc2/N=C/c2ccccc2O)c1</smiles>

\section{Complexes}

Elemental analyses indicate that the complexes of $\mathrm{H}_{2} \mathrm{~L}$ with $\mathrm{Cu}$ (II), Co (II) and $\mathrm{Mn}$ (II) can be formulated as $\mathrm{M} \cdot \mathrm{L}$. The disappearance of the $\mathrm{OH}$ band of the free ligand in the IR of the metal complexes indicates that the $\mathrm{OH}$ group is deprotonated and coordinated to the metal ion as $-\mathrm{O}^{-}$. On the other hand, the $\mathrm{C}=\mathrm{N}$ stretching mode is shifted to a lower frequency by about $29 \mathrm{~cm}^{-1}$, compared to the free ligand. These IR results indicate that the ligand is coordinated to $\mathrm{Cu}$ (II), $\mathrm{Co}$ (II), $\mathrm{Mn}$ (II) via both $\mathrm{N}$ and $\mathrm{O}$. The new IR bands appearing at $420 \sim 430 \mathrm{~cm}^{-1}$ and $541 \sim 560 \mathrm{~cm}^{-1}$ are assigned to $v$ (M-O) and $v(\mathrm{M}-\mathrm{N})$ vibrations, respectively. In addition, no new bands at $1610 \sim 1550 \mathrm{~cm}^{-1}$ and $1420 \sim 1300$ $\mathrm{cm}^{-1}$ are observed, indicating that the complexes do not contain $\mathrm{CH}_{3} \mathrm{COO}^{-}$anions, which is in accordance with the elemental analysis results for the complexes. According to the aforementioned data, we propose for the complexes prepared the structure shown in Figure 2. It is suggested that the complexes are square planar or nearly square planar, coordinated according to the common stereochemistry of this kind of compounds.

Figure 2. The proposed chemical structure for the transition metal complexes

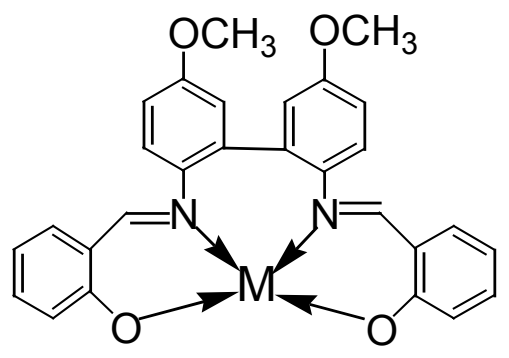

$$
\mathrm{M}=\mathrm{Cu} \text { (II), } \mathrm{Co} \text { (II), } \mathrm{Mn} \text { (II) }
$$




\section{Electrochemistry}

The electrochemical behaviors of the $\mathrm{H}_{2} \mathrm{~L}$ ligand and the $\mathrm{MnL}, \mathrm{CuL}$ and $\mathrm{CoL}$ complexes were examined by means of cyclic voltammetry in $\mathrm{CH}_{2} \mathrm{Cl}_{2}$. A typical cyclic voltammogram of $\mathrm{H}_{2} \mathrm{~L}$ and its complexes is shown in Figure 3 and the results are summarized in Table 1.

Table 1 Cyclic voltammetric data for ligand and complexes in $\mathrm{CH}_{2} \mathrm{Cl}_{2}$

\begin{tabular}{cccccc}
\hline $\begin{array}{c}\text { Ligand and } \\
\text { Complexes }\end{array}$ & $\mathrm{E}_{\mathrm{p}, \mathrm{a} 1} / \mathrm{V}$ & $\mathrm{E}_{1 / 2} / \mathrm{mV}$ & $\Delta \mathrm{Ep}_{1} / \mathrm{mV}$ & $\mathrm{E}_{\mathrm{p}, \mathrm{a} 2} / \mathrm{V}$ & $\mathrm{E}_{1 / 2}^{\prime} / \mathrm{mV}$ \\
\hline $\mathrm{L}$ & 0.8579 & 782.4 & 75.5 & - & - \\
$\mathrm{MnL}$ & 0.580 & 495.0 & 110.0 & 0.895 & 800.0 \\
$\mathrm{CuL}$ & 0.830 & 745.0 & - & - & - \\
$\mathrm{CoL}$ & 0.782 & 700.0 & - & - & - \\
\hline
\end{tabular}

The MnL complex shows two oxidation processes at $\mathrm{E}_{\mathrm{p}, \mathrm{a}}=0.58$ and $0.895 \mathrm{~V}$. The first wave is nearly reversible with $\Delta \mathrm{Ep}=110 \mathrm{mV}$. This process is consistent with a one-electron oxidation to form the mixed valence Mn(II, III) species. The second wave is irreversible at $0.895 \mathrm{~V}$. On the other hand, the complexes of $\mathrm{CuL}$ and $\mathrm{CoL}$ only show one oxidation process at 0.83 and $0.782 \mathrm{~V}$, respectively, which are irreversible. This process is attributed to the oxidation of ligand. The observed reaction voltages of the complexes of $\mathrm{CuL}$ and $\mathrm{CoL}$ are lower than that of the ligand, while the $\mathrm{MnL}$ one is higher.

Figure 3. Cyclic Voltamogram of the Complexes in $\mathrm{CH}_{2} \mathrm{Cl}_{2}$; $\mathrm{Scan}$ Rate $100 \mathrm{mV} / \mathrm{s}$

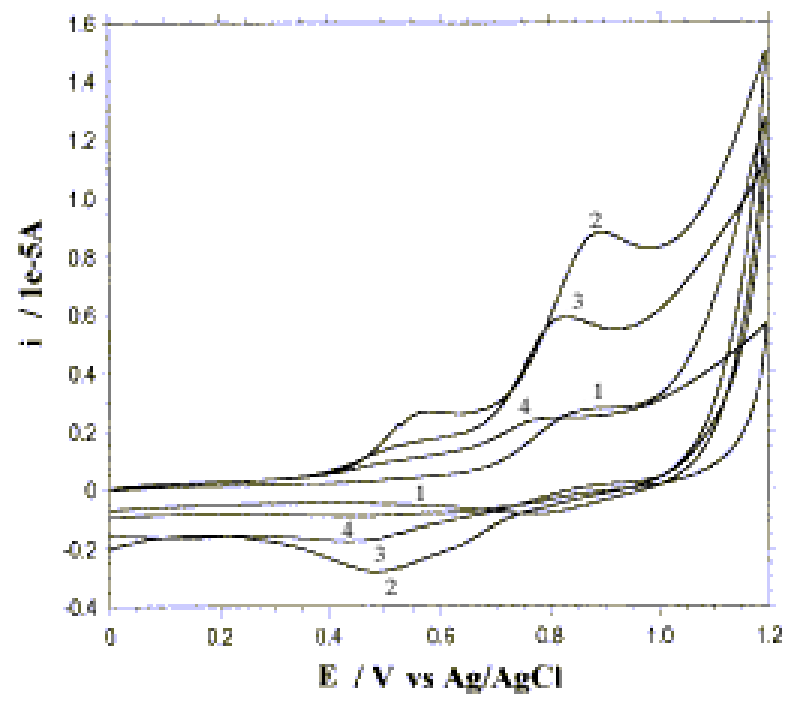

1- L, 2-MnL, 3-CuL, 4-CoL. 


\section{Acknowledgments}

We thank National Natural Science Foundation of China (No. 29871014) and the Doctoral Foundation of Lanzhou University for financial support.

\section{Experimental}

\section{General}

The $\mathrm{C}, \mathrm{H}, \mathrm{N}$ data were determined using a Varian EL elemental analyzer. IR spectra was recorded on a Nicolet 170SX FT IR spectrophotometer using KBr discs in the range $v=400-4000 \mathrm{~cm}^{-1}$. The cyclic voltammetry experiments were carried out using a CHI660A electrochemical workstation (Covarda, USA). All chemicals were analytical grade and used without further purification.

\section{Preparation of the Ligand}

Salicylicaldehyde $(20 \mathrm{mmol})$ was added to a solution of 2,2' -bi(p-methoxyphenylamine) (10 $\mathrm{mmol})$ in ethanol $(30 \mathrm{~mL})$. The mixture was continuously stirred for $3 \mathrm{~h}$ at room temperature, and the resulting yellow product was collected by filtration to give pale white crystals in 94\% yield. Calculated for $\mathrm{C}_{28} \mathrm{H}_{24} \mathrm{~N}_{2} \mathrm{O}_{4}: 74.3 \%$ C, $5.4 \% \mathrm{H}, 6.2 \% \mathrm{~N}$. Found: $73.9 \% \mathrm{C}, 5.6 \% \mathrm{H}, 6.1 \% \mathrm{~N}$. IR (in $\mathrm{KBr}$ pellets) $\mathrm{cm}^{-1}: 1657(-\mathrm{C}=\mathrm{N}-), 3450(-\mathrm{OH}) \mathrm{cm}^{-1}$.

\section{Preparation of the Complexes}

A mixture of $\mathrm{M}(\mathrm{OAc})_{2} \cdot \mathrm{nH}_{2} \mathrm{O}(2 \mathrm{mmol})[\mathrm{M}=\mathrm{Mn}(\mathrm{II}), \mathrm{Co}(\mathrm{II}), \mathrm{Cu}$ ( II )], $\mathrm{LiOH}$ and ligand in a 1:2:1 molar ratio was stirred in ethanol $(20 \mathrm{~mL})$ at $50^{\circ} \mathrm{C}$ for $4 \mathrm{~h}$. The crude complexes were filtered off and then recrystallized from 1:1 water-ethanol. The products were dried in vacuo for $48 \mathrm{~h}$.

CuL: brown solid, yield, $85 \%$; Calculated for $\mathrm{C}_{28} \mathrm{H}_{22} \mathrm{~N}_{2} \mathrm{O}_{4} \mathrm{Cu}: 65.4 \% \mathrm{C}, 4.3 \% \mathrm{H}, 5.5 \%$ N. Found: $65.2 \%$ C, $4.6 \% \mathrm{H}, 5.7 \%$ N. IR cm $\mathrm{cm}^{-1}$ : $1628(-\mathrm{C}=\mathrm{N})$.

CoL: orange solid, yield, $88 \%$; Calculated for $\mathrm{C}_{28} \mathrm{H}_{22} \mathrm{~N}_{2} \mathrm{O}_{4} \mathrm{C}: 66.0 \% \mathrm{C}, 4.4 \% \mathrm{H}, 5.5 \% \mathrm{~N}$. Found: $65.8 \%$ C, $4.3 \% \mathrm{H}, 5.7 \%$ N. IR cm $\mathrm{cm}^{-1}: 1629(-\mathrm{C}=\mathrm{N})$.

MnL: dark-brown solid, yield, $88 \%$; Calculated for $\mathrm{C}_{28} \mathrm{H}_{22} \mathrm{~N}_{2} \mathrm{O}_{4} \mathrm{Mn}: 66.5 \% \mathrm{C}, 4.4 \% \mathrm{H}, 5.5 \% \mathrm{~N}$. Found: $66.8 \% \mathrm{C}, 4.1 \% \mathrm{H}, 5.2 \% \mathrm{~N}$. IR cm $\mathrm{cm}^{-1}: 1628(-\mathrm{C}=\mathrm{N})$ 


\section{Electrochemical Measurements}

The cyclic voltammetry experiments were carried out with a three electrode apparatus using a CHI660A electrochemical workstation (Covarda, USA), the working electrode was a glassy carbon disc, polished with an $\mathrm{Al}_{2} \mathrm{O}_{3}$ suspension prior to every experiment. $\mathrm{Ag} / \mathrm{AgCl}$ and $\mathrm{Pt}$ foil were used as reference and counter electrodes, respectively. The $\mathrm{H}_{2} \mathrm{~L}$ and complexes solutions $\left(1.0 \times 10^{-3} \mathrm{~mol}^{\cdot} \mathrm{L}^{-1}\right)$ in $\mathrm{CH}_{2} \mathrm{Cl}_{2}$, with tetraethylammonium perchlorate $\left(0.1 \mathrm{~mol} \cdot \mathrm{L}^{-1}\right)$ as supporting electrolyte were purged of oxygen by bubbling nitrogen for $15 \mathrm{~min}$. and then blanketed with the same gas during the experiments. All compounds were investigated at $25^{\circ} \mathrm{C}$. The voltammograms were recorded with a potential scan of $100 \mathrm{mV} \cdot \mathrm{s}^{-1}$.

\section{References}

1. Djebbar, S. S.; Benali, B. O.; Deloume, J. P. Synthesis, characterization and electrochemical behavior of copper(II) complexes with linear and tripodal tetradentate ligands derived from Schiff bases. Polyhedron, 1997, 16, 2175-2182

2. Bhattacharyya, P.; Parr, J.; Ross, A. T. First synthesis of a unique dilead Schiff base complex. $J$. Chem. Soc. Dalton. 1998, 3149-3150

3. He, L.; Gou, S. H.; Shi, Q. F. The formation of a Schiff base intermediate: a nickel(II) complex of an asymmetric tripodal ligand. J. Chem. Crystallogr. 1999, 29, 207-210

4. Wu, J. C.; Tang, N.; Liu, W. S.; Tan, M. Y.; Chan, A. S. C. Intramolecular hydrogen bond self-template synthesis of some new Robson-type macrocyclic ligands. Chin. Chem. Lett. 2001,12, 757-760

5. Liu, C. M.; Xiong, R. G.; You, X. Z.; Liu, Y. J.; Cheung, K. K. Crystal structure and some properties of a novel potent $\mathrm{Cu}_{2} \mathrm{Zn}_{2} \mathrm{SOD}$ model Schiff base copper(II) complex. Polyhedron, 1996, $15,4565-4571$

6. Djebbar, S. S.; Benali, B. O.; Deloume, J. P. Synthesis, characterization, electrochemical behavior and catalytic activity of manganese(II) complexes with linear and tripodal tetradentate ligands derived from Schiff bases. Transit. Metal. Chem. 1998, 23, 443-447

7. Hamada, Y. J. The development of chelate metal complexes as an organic electroluminescent material. IEEE Trans.Electron Devices, 1997, 44, 1208-1217

Sample availability: Not available.

(C) 2003 by MDPI (http://www.mdpi.org). Reproduction is permitted for noncommercial purposes. 